\title{
Scenarios for sustainable management of plant parasitic nematodes
}

\author{
B. B. Westerdahl ${ }^{1}$ (D)
}

Received: 30 September 2020 / Revised: 17 April 2021 / Accepted: 21 April 2021 / Published online: 6 May 2021 (c) The Author(s) 2021

\begin{abstract}
Plant parasitic nematodes cause significant yield reductions worldwide. Before development of soil fumigation, sustainable practices were developed for nematode management; but were utilized with limited success. The restricted availability of fumigants and other nematicides, has stimulated a return to research into more sustainable management scenarios. In recent years, new tools have been developed that improve the successful utilization of sustainable methods including: nematode resistant crop varieties, trap cropping, biofumigation, molecular identification techniques, databases that can be accessed online to search for crops resistant to nematodes, relatively inexpensive soil temperature dataloggers, nematode degree-day models, research on nematode biology and population cycling, development of less toxic chemicals, and development of new soil amendments and natural products. Combining these with a strong nematode control and certification program for nursery crops, have made it possible to develop promising scenarios to reduce damaging nematode populations and increase yields.
\end{abstract}

Keywords Nematode $\cdot$ Sustainable $\cdot$ Trap cropping $\cdot$ Biofumigation $\cdot$ Nursery certification $\cdot$ Resistant varieties

\section{Introduction}

A United Nations Resolution called the "The 2030 Agenda", contains a collection of 17 Sustainable Development Goals (SDGs) that have the global aim of creating a better and more sustainable future (United Nations Department of Economic and Social Affairs). Annually, yield losses caused by plant parasitic nematodes are estimated between 5 and $12 \%$ worldwide (Sasser and Freckman 1987). Although more than 4100 species of plant-parasitic nematodes have been identified, and together are estimated to cause up to $\$ 118$-billion dollars of damage to crops each year, there is general agreement that Root-knot (Meloidogyne sp.), cyst (Heterodera sp, Globodera sp.), and root-lesion (Pratylenchus sp.) are the three major groups of nematodes affecting agricultural production worldwide (Lamberti 1997). There are excellent recent reviews on management of plant parasitic nematodes worldwide (Barker and Koenning 1998; Bernard et al 2017; Jones et al. 2013) and in India (Khan 2015). The goal of this review is to provide scenarios that demonstrate how recent developments in the management of these three groups of

B. B. Westerdahl

bbwesterdahl@ucdavis.edu

1 Department of Entomology and Nematology, University of California, Davis, CA, USA plant parasitic nematodes contribute to achieving 14 of the SDGs. The basic principles outlined in the scenarios can be extended to additional cropping systems.

For the benefit of those from other disciplines who may chance upon this review in a literature search, the following brief description of nematode biology relevant to sustainable management will be helpful. Plant-parasitic nematodes are typically soil dwelling, microscopic roundworms that feed on the roots of plants. Dramatic damage symptoms may be seen on crops however, the largest plant parasitic nematodes are small enough to sit on the head of an ordinary sewing pin. Nematodes are aquatic organisms small enough to move in the film of water that lines soil pores.

The parts of the life cycle are: adult, egg, and four juvenile stages with a molt between stages. There are three life history patterns to consider for sustainable management programs: ectoparasitic in which adults, eggs and juveniles occur within soil; migratory endoparasitic in which adults, eggs and juveniles can be in roots or in soil; and sedentary endoparasitic in which sedentary adults are found in roots, eggs are either in soil or roots, and a migratory infective juvenile penetrates a root, establishes a feeding site and becomes sedentary (Westerdahl 2011). 


\section{Historical background}

As late as the mid-1970's, nematicides such as methyl bromide, DBCP (1,2-dibromo-3-chlorpropane), EDB (ethylene dibromide), and metam sodium were considered safe products that any home gardener could purchase off the shelf at their local garden supply store. Today, these same products are either highly restricted, or banned altogether, and this has stimulated the search for more sustainable management methods.

As we move away from chemical management of nematodes towards more sustainable methods, we are also moving away from solutions that were applicable worldwide, to more localized solutions based on nematode biology and ecology in particular agricultural niches.

A misconception in the use of sustainable practices for nematode management is that this is a new area of research. In reality, as illustrated by the following quote from a textbook of nematology written in 1961, previous nematologists put considerable effort into developing sustainable practices (Thorne 1961). 'It is fitting that a few words of commendation be given to the officials of the Shell Chemical Corporation and The Dow Chemical Company for their foresight in pioneering the field of soil fumigation; their efficient, generous, cooperative, and persistent campaigns have carried the science of soil fumigation into almost every country. Those of us who had spent many years attempting to control nematodes by crop-rotation and cultural methods, often with futile, discouraging results, now realized the satisfaction of recommending D-D and EBD for the control of nematodes on certain moderate- and high-priced crops'.

Fumigation was efficacious because fumigants follow gas laws and move through the air phase in soil pores. They then dissolve in the water phase to kill nematodes. Fumigants were also less expensive than sustainable practices. The fumigants promoted by Thorne are no longer available because of concerns regarding carcinogenicity and groundwater contamination. Other fumigants are restricted owing to unhealthy concentrations in the air or potential for destruction of the ozone layer (United States Environmental Protection Agency 2009).

Since the time of Thorne's writing, new tools have been developed that improve the successful utilization of sustainable methods including: nematode resistant crop varieties, trap cropping, biofumigation, molecular identification techniques, databases that can be accessed online to search for crops resistant to nematodes, relatively inexpensive soil temperature dataloggers, nematode degree-day models, research on nematode biology and population cycling, development of less toxic chemicals, and development of new soil amendments and natural products.

\section{Scenario: Collaboration between India and the University of California (Partnerships for the Goals, Quality Education, Gender Equality, and Reduced Inequalities)}

Partnerships for the Goals are a component of this and all future scenarios. Examples of long-term partnerships between India and the University of California (UC) illustrate progress towards this goal and those of Quality Education, Gender Equality, and Reduced Inequalities. Foremost among these partnerships are collaborations initiated by Ron Mankau from UC Riverside and D. J. Raski from UC Davis. As a Fulbright Research Fellow, Reinhold (Ron) Mankau, worked at the Indian Agricultural Research Institute in New Delhi from 1956 to 1958. Following this, from 1964 to 1965, he was a Fulbright Senior Postdoctoral Fellow at the Agricultural College and Research Institute in Coimbatore, India. From 1973 to 1974, he participated in the United Nations Development Program as a Consultant at the University of Agricultural Science, Hebbal, Mysore. Professor Emeritus Mankau was an early leader in biological control and sustainable methods of nematode management. Frequent citations of his publications in the Indian Journal of Nematology are evidence of his influence in this area (Raski et al. 2002).

D. J. (Dewey) Raski was the first chair of the Department of Nematology that was established at UC Davis in 1954. Professor Raski worked in India in 1963 at the New Delhi Indian Agricultural Research Institute as part of the Rockefeller Foundation Indian Agriculture Project. He is an Honorary Fellow of the Nematological Society of India (NSI) that was founded in 1969 (Raski et al. 2002). The first issue of the Indian Journal of Nematology was published in 1971. Evidence of the success of this collaboration is the Professor D.J. Raski Academic Merit Award presented by the society for the best paper presentation by a member below the age of 35 years at the Society's meeting every 2 years (http:// nematology.in/awards/raski-award/). Professor Raski's work in systematics includes descriptions of species found in India and his research has been frequently cited in the Indian Journal of Nematology. Dewey and his wife Elaine also created a family like atmosphere for students from India studying at UC Davis.

Table 1 Students from India receiving PhD's from UC Davis:

\begin{tabular}{ll}
\hline 1961 Alleppey R. Seshadri & 1970 Usha K. Mehta \\
1964 George I. D’Souza & 1983 John Chitambar \\
1966 Sitanath Das & 1993 Umesh Kodira \\
1968 Dipes R. Dasgupta & \\
\hline
\end{tabular}

Source: Raski et al. 2002 
More than 90 students including many from foreign countries have completed PhDs or Masters degrees at UC Davis. This includes seven students from India that received $\mathrm{PhDs}$ at UC Davis (Table 1). Subsequently, these students have trained additional students and made major contributions to the discipline of nematology both in India and in the United States. Additionally, more than 50 Visiting Scientists and Post-Doctorals from more than 30 countries have conducted research at UC Davis, with five of these being from India (Table 2) (Raski et al. 2002). The Partnerships between India and UC illustrate how bringing people from around the world together can achieve Quality Education, Gender Equality, and Reduce Inequalities.

\section{Scenario: Sustainability through prevention of nematode problems (Industry Innovation and Infrastructure; and Peace, Justice, and Strong Institutions)}

Nursery stock produced in California is distributed throughout the world. An important sustainable method of managing nematodes is to prevent them from getting into a field in the first place. For example, once you plant an infested strawberry plant or an infested rootstock, the land can become infested and you no longer will be able to eradicate the problem. This is an economical and sustainable method because, for example, 1 ha of nursery area plants approximately 100 ha of fruit and nut tree production. Through measures to prevent spread of nematode infested planting material, the California Department of Food and Agriculture (CDFA) Nursery Services Program has been instrumental in keeping nematodes as a relatively minor pest compared to other pest management disciplines. Two of the PhDs from India trained at UC Davis play a major role in this endeavor. Umesh Kodira is Branch Chief of the CDFA Plant Pest Diagnostic Center, and John Chitambar is the Senior Plant Nematologist in this group.

Soon after nematology became a recognized discipline in the state, legislation was passed in 1960 for the 'Approved Treatment and Handling Procedures for the Control of Nematodes in Deciduous Fruit and Nut Tree, Grapevine, Berry and Vegetable Plant Growing Ground Inspection Program'. This program has been instrumental in insuring nematode free nursery stock is produced by California growers. This

Table 2 Visiting scholars and post-doctorals from India visiting UC Davis:

1971 Gopal Swarup

1981-83 Usha K. Mehta

1985 Chellapau Mohandas

Source: Raski et al. 2002 program specified that nursery fields had to be sampled for plant parasitic nematodes. Sampling was waived if the land was fumigated prior to planting. This legislation was developed as a result of recommendations by the state's Nematode Study Committee composed of members from the Department of Agriculture, the University of California, County Agricultural Commissioners, the Nursery Industry, and the Chemical Industry. This program continues under the CDFA's Nursery Stock Nematode Control Program (NIPM \#7) that specifies soil treatment and handling procedures to ensure field and container grown nematode-free nursery stock for farm planting (Chitambar et al. 2018). Industry Innovation played a key role in the development of legislation and government Infrastructure for the prevention of nematode problems and this contributes to Peace, Justice, and Strong Institutions.

\section{Scenario: Reduce fumigant use by prolonging orchard life through post plant treatments (Climate Action and Climate Change)}

In recent years, extensive research has been conducted to find replacements for methyl bromide, widely used as a preplant soil fumigant before being implicated in the depletion of ozone in the stratosphere and contributing to climate change. A way to reduce the frequency of fumigant use in perennial crops is through prolonging the life of existing orchards. The longer an orchard remains healthy and productive, the less often if will be terminated, fumigated, and replanted. Over time, this reduces the amount of fumigant used. To replace fumigation, a variety of approaches have been researched for management of plant parasitic nematodes including development of pre-plant hot water treatments of rootstocks, evaluation of rootstock susceptibility, and evaluation of biological products (Buzo et al. 2009; Giraud et al. 2011; Hasey et al. 2004; Westerdahl and Radewald 2011).

Worldwide, California is the second largest producer of walnuts. Recently, two biological nematicides achieved registration in California for use on walnuts and other crops, DiTera (a toxin from the fungus Myrothecium verrucaria) and Nema-Q (extracted from Quillaja saponaria the soap bark tree). Root-lesion, Pratylenchus vulnus, and ring, Mesocriconema xenoplax are the major nematode problems on walnuts (Juglans $\mathrm{sp}$ ). In addition to decreasing yields, nematode feeding damages roots and stresses trees. A partnership formed between UC Cooperative Extension (CE) specialists in nematology and pomology, UC CE Farm Advisors in the counties where trials were conducted, local growers, the California Walnut Marketing Board, and industry representatives conducted field trials with these products 
demonstrating increases in walnut yield, and tree growth and vigor. An unexpected finding was that although in some cases nematode populations were reduced, in other cases populations increased along with increases in yield and growth (Westerdahl et al. 2013). Apparently, a healthier root system developed that could support more nematodes. Reducing the frequency of use of fumigant nematicides in perennial crops through prolonging the life of existing orchards contributes to the goals of Climate Action and Climate Change.

\section{Scenario: From Temik to transgenic, managing lesion nematode (Pratylenchus penetrans) on Easter lilies (Clean Water and Sanitation, Life Below Water, Decent Work and Economic Growth)}

This scenario illustrates the long-term nature and complexity of the development of a sustainable nematode management program. The partnership for this endeavor involved UC CE Nematology Specialists, UC CE Farm Advisors, Oregon State CE Farm Advisors, the Northwest California Resource Conservation and Development Council, the Easter Lily Research Foundation, the California Department of Food and Agriculture Specialty Crop Block Grant program, the USDA-ARS Floral \& Nursery Plants Research Unit, and industry representatives.

In the 1940's, Easter lily (Lilium longiflorum Thunb.) bulbs began to be grown commercially in Curry County, Oregon (OR), and in Humboldt and Del Norte counties of California (CA), USA. The industry contributes to decent work and economic growth for the area. Raising a successful crop requires managing nematodes in both soil and planting stock. In the past, this has resulted in nematicide contamination of the shallow groundwater in the growing area (Westerdahl and Giraud 2017).

Beginning in 1988, UC Davis researchers and UC CE Farm Advisors began conducting yearly trials at the Easter Lily Research Foundation Research Station funded by growers to develop sustainable management techniques for the lesion nematode Pratylenchus penetrans. The research cycle follows grower standard practices beginning with planting the trial in October. A few days before Easter (March-April) researchers meet with the growers to discuss previous trial results, plan future trials, and to judge new varieties being developed by the research station manager. At a field day in June, researchers meet with the growers to tour the research trials and explain the treatments being tested. Trials are harvested in September, again following grower standard practices.

Between 1988 and 1990, drip irrigation applications of a number of products were tested. From 1991 to 1996 studies were conducted on crop rotation, nematode population dynamics, and hot water treatment of planting stock (Westerdahl et al. 1998). From 1996 to 2002 ozone treatments of planting stock and soil were developed (Giraud et al. 2011). Between 2002 and 2014 trials were conducted with bionematicides and natural product treatments of planting stock and soil (Westerdahl et al. 2017). As a result of the trials, California registrations were obtained for DiTera, Nema-Q, Neem (Azadirachta indica, a product of Indian origin), and MeloCon (Paecilomyces lilacinus Strain PL251). Simultaneously to this research, a breeding program was conducted by the research station manager to develop a lily that would mature in 2 years as opposed to 3 years. This resulted in a reduction in pesticide usage by not having to plant the bulbs a third year. From 2013 to 2015, a cooperative project was conducted with the USDAARS Floral \& Nursery Plants Research Unit that involved the development of lilies with a nematode resistant cystatin gene (Vieira 2017). The gene was transferred into the lilies by the USDA and 3 years of field testing was conducted with the nematode resistant lilies. As a result of this program, a number of alternatives were developed from which growers could select and combine into a program meeting their particular needs. Sustainable management methods developed through research on the Easter Lily cropping system reduces potential for contamination of surface and ocean waters while providing significant employment for the area. This contributes to the goals of Clean Water and Sanitation, Life Below Water, and Decent Work and Economic Growth.

\section{Scenario: Improve nematode management on annual crops through use of cultural practices (Life On Land, Zero Hunger, Responsible Consumption and Production)}

This scenario addresses two primary nematodes of interest on annual crops. These are root-knot nematode (Meloidogyne sp) that causes galls on roots of many different crops, and the sugar beet cyst nematode (Heterodera schachtii) a pest on sugar beets and brassica crops. Trap cropping, biofumigation, and use of resistant varieties are effective methods to reduce the use of chemical nematicides. This contributes to less exposure of humans and nontargets to toxins and increases potential for organic food production, contributing to the goals of Life on Land, Zero Hunger, and Responsible Consumption and Production.

\section{Trap cropping}

Trap cropping can be utilized for sedentary endoparasitic nematodes such as root-knot and cyst nematode (Barker and Koenning 1998; Khan 2015; Westerdahl 2020). A trap crop can be any crop that is a host to the nematode of concern, 
relatively inexpensive to grow, and amenable to the grower's cultural practices. For example, in a carrot cropping system Westerdahl (2020) utilized carrots as both the trap crop for root-knot nematode $M$. javanica, and the subsequent commercial crop. For the cereal cyst nematode (Heterodera avenae) growing wheat cultivar C-306 has been used as a trap crop before growing the main crop (Khan 2015).

Trap cropping is effective because once an infective juvenile penetrates a host root and begins to feed, it becomes rotund and is trapped within the root. Destruction of the host prior to nematodes laying eggs results in death of the nematodes within the roots. The timing of crop termination is critical for the success of the method. Nematodes develop more rapidly in warmer than in cooler soil. Therefore, a warmer growing area would require earlier trap crop termination for successful nematode control than a cooler area. Different species of root-knot nematode require different numbers of nematode degree days (heat units) for development, so it is important to know the species present in a particular field. This management tool, as well as others not utilizing fumigants, highlights the importance of accurately knowing the species of nematode present in a given field in order to be successful. Recently developed molecular identification techniques are of value in the implementation of trap cropping (Williamson et al. 1997). In California, the statewide California Irrigation Management Information System (CIMIS) records soil temperature data from which estimates can be made on the timing of trap crop termination through a degree day calculator (http://ipm.ucanr. edu/WEATHER/index.html).

The cost of a new management technique is always an issue. Trap cropping requires irrigation to grow the trap crop or to germinate nematode susceptible weeds. This plus the cost of trap crop seeds, planting the seeds, and crop termination are the major expenses. The major chemical control methodologies currently in use on vegetable crops in California require the use of irrigation, either as part of the application process as in water applications of metam sodium products, or to seal the soil surface to minimize emissions. Therefore, the cost of irrigation needed for trap cropping might be similar to that for a fumigant nematicide application and, overall, less costly than the fumigant application. Germinating weeds followed by timely crop termination prior to development of seeds also provides the benefit of weed control at no additional cost. If a field has weed species that are hosts to the nematodes present, then the weeds themselves could act as the trap crop.

\section{Biofumigation}

Considerable research has been devoted to investigate the use of biofumigation to manage nematodes, weeds and fungi (Angus et al. 1994; Desmedt et al. 2020; Dutta 2019;
Stapleton and Duncan 1998). Broccoli and other species of Brassica contain secondary metabolites called glucosinolates. Tilling brassicas into the soil results in production of isothiocyanates during degradation. Interestingly, the nematicide metam sodium contains isothiocyanate as an active ingredient. Soil fumigation uses tarping with plastic film to reduce the rate of volatilization from a field. A similar technique improves the efficacy of biofumigation (Stapleton and Duncan 1998).

\section{Resistant varieties}

When available, resistant plant varieties have proven useful in managing plant parasitic nematodes. For example, cultivars resistant to various species of root-knot nematode are available for tomatoes, alfalfa, tobacco, grapevines, fruit tree rootstocks, soybeans, lima beans, cotton, sweet potatoes and coffee (Desmedt et al. 2020; Khan 2015). With respect to nematode host status, a particular plant species can be classified as either susceptible (high level of reproduction), moderately susceptible (nematode reproduction somewhat reduced), moderately resistant (reproduction considerably reduced), resistant (reproduction severely suppressed), or immune (no evidence of feeding or reproduction). It is possible that susceptible crops will be tolerant and not exhibit damage or yield loss. It is important to distinguish between these cultivars and those that are truly resistant or immune and do not allow nematode reproduction. If reproduction is not possible on the resistant variety, and nematodes present at planting are no longer viable, a susceptible crop can often be planted the following year (Chitambar 2018). The study of secondary plant metabolites known as ANP's (antinematode phytochemicals) and mechanisms for nematode resistance could contribute to new management strategies (Desmedt et al. 2020).

Resistant varieties are used in the management of soybean cyst nematode (Heterodera glycines) on soybeans (Barker and Koenning 1998; Desmedt et al. 2020). Sugarbeet cyst nematode (Heterodera schachtii) is found in more than 40 countries. Eleven percent of the sugarbeet growing area in the Imperial Valley of California has been shown to be infested (Chitambar et al. 2018). Breeding programs to develop sugar beets resistant to cyst nematode have been in progress for many years. Recently, the industry has made resistant varieties available for testing in field trials in the Imperial Valley by a partnership composed of UC Davis CE Specialists, USDA-ARS, Imperial County UC CE, UC Agriculture and Natural Resources (ANR) Sugarbeet Workgroup, UC ANR Desert Research and Extension Center, Growers, California Beet Growers Association (CBGA), Holly Sugar, seed companies, Pest Control Advisors (PCAs), and industry. 
Field trials conducted on UC and USDA-ARS research stations have demonstrated that in infested fields these new varieties are resistant to cyst nematode and produce yields greater than those achieved following traditional fumigation. However, nematode resistant commercial varieties do not always yield higher than susceptible varieties unless there is a high nematode population (Richardson 2011).

\section{Conclusion}

Through the preceding scenarios, examples have been presented to illustrate ways in which nematology and nematologists have contributed towards achieving the UN Sustainable Development Goals. Partnerships between India and UC illustrate how bringing people from around the world together can achieve Quality Education, Gender Equality, and Reduce Inequalities. Industry Innovation played a key role in the development of legislation and government Infrastructure for the prevention of nematode problems and this contributes to Peace, Justice, and Strong Institutions. Reducing the frequency of use of fumigant nematicides in perennial crops through prolonging the life of existing orchards contributes to the goals of Climate Action and Climate Change. Sustainable management methods developed through research on the Easter Lily cropping system reduces potential for contamination of surface and ocean waters while providing significant employment for the area. This contributes to the goals of Clean Water and Sanitation, Life Below Water, and Decent Work and Economic Growth. Trap cropping, biofumigation, and use of resistant varieties are effective methods to reduce the use of chemical nematicides. This contributes to less exposure of humans and nontargets to toxins and increases potential for organic food production, contributing to the goals of Life on Land, Zero Hunger, and Responsible Consumption and Production.

\section{Declarations}

Conflict of interest On behalf of all authors, B. B. Westerdahl states that there is no conflict of interest.

Open Access This article is licensed under a Creative Commons Attribution 4.0 International License, which permits use, sharing, adaptation, distribution and reproduction in any medium or format, as long as you give appropriate credit to the original author(s) and the source, provide a link to the Creative Commons licence, and indicate if changes were made. The images or other third party material in this article are included in the article's Creative Commons licence, unless indicated otherwise in a credit line to the material. If material is not included in the article's Creative Commons licence and your intended use is not permitted by statutory regulation or exceeds the permitted use, you will need to obtain permission directly from the copyright holder. To view a copy of this licence, visit http://creativecommons.org/licenses/by/4.0/.

\section{References}

Angus JF, Gardner PA, Kirkegaard JA, Desmarchelier JM (1994) Biofumigation: isothiocyanates released from Brassica roots inhibit growth of take all fungus. Plant Soil 162:107-112

Barker KR, Koenning SR (1998) Developing sustainable systems for nematode management. Annu Rev Phytopathol 36:165-205

Bernard GC, Egnin M, Bonsi C (2017) Chapter 7 The impact of plantparasitic nematodes on agriculture and methods of control. In: Shah MM, Mahamood M (eds) Nematology concepts diagnosis and control. IntechOpen, pp 121-151. https://www.intechopen. com/books/nematology-concepts-diagnosis-and-control

Buzo T, McKenna KS, Anwar SA, McKenry MV (2009) VX211, a vigorous new walnut hybrid clone with nematode tolerance and a useful resistance mechanism. J Nematol 41:211-216

Chitambar JJ, Westerdahl BB, Subbotin SA (2018) Chapter 6 Plant parasitic nematodes in California agriculture. In: Subbotin SA, Chitambar JJ (eds) Plant parasitic nematodes in sustainable agriculture of North America Volume 1: Canada, Northeastern, Midwestern and Southern USA. Springer, Switzerland, pp 131-192

Desmedt W, Mangelinckx S, Kyndt T, Vanholme B (2020) A phytochemical perspective on plant defense against nematodes. Front Plant Sci 11:1-25

Dutta KD (2019) Plant-parasitic nematode management via biofumigation using brassica and non-brassica plants: current status and future prospects. Curr Plant Biol 17:17-32

Giraud D, Riddle LJ, Anderson CE, Westerdahl BB (2011) New products to improve growth of field grown Easter lily bulbs. Acta Hortic 900:333-337

Hasey JK, Westerdahl BB, Lampinen B (2004) Long-term performance of own-rooted "Chandler" walnut compared to "Chandler" walnut on Paradox rootstock. Acta Hortic 636:83-86

Jones JT, Haegeman A, Danchin EGJ, Gaur HS, Helder J, Jones MGK, Kikuchi T, Manzanilla-Lopez R, Palomares-Rius JE, Wesemael WML, Perry RN (2013) Top 10 plant-parasitic nematodes in molecular plant pathology. Mol Plant Pathol 14:946-961

Khan MR (2015) Chapter 16 Nematode diseases of crop in India. In: Awasthi LP (ed) Recent advances in the diagnosis and management of plant diseases. Springer, India, pp 183-224

Lamberti F (1997) Plant nematology in developing countries: problems and progress. FAO Corporate Document Repository. http://www. fao.org/docrep/V9978E/v9978e05.htm. Accessed 16 Sept 2020

Raski D, Thomason IJ, Chitambar J, Ferris H (2002) A history of nematology in California (as of September 2002), p 120. http:// nemaplex.ucdavis.edu/History $\% 20$ of $\% 20$ Nematology $\% 20 \mathrm{in} \%$ 20California.pdf. Accessed 16 Sep 2020

Richardson KL (2011) Sugar beet traditional breeding. Sugar Tech 12:181-186

Sasser JN, Freckman DW (1987) A world perspective on nematology: the role of the society. In: Veech JA, Dickson DW (eds) Vistas on nematology. Society of Nematologists Inc, Maryland, pp 7-14

Stapleton JJ, Duncan RA (1998) Soil disinfestation with cruciferous amendments and sublethal heating: effects on Meloidogyne incognita, Sclerotium rolfsii and Pythium ultimum. Plant Pathol 47:737-742

Thorne G (1961) Principles of nematology. McGraw-Hill Book Company, New York

United Nations Department of Economic and Social Affairs (2020) Sustainable development: the 17 goals. https://sdgs.un.org/goals. Accessed 16 Sep 2020

United States Environmental Protection Agency (2009) Ozone layer depletion-regulatory programs. http://www.epa.gov/ozone/mbr. Accessed 16 Sep 2020

Vieira P, Lakshman DK, Pandey R, Slovin JP, Kamo KK (2017) Symptom development in response to combined infection of in vitro 
grown Lilium longiflorum with the root lesion nematode Pratylenchus penetrans and soilborne fungi collected from diseased roots of field-grown lilies. Plant Dis 101:1-8

Westerdahl B (2011) Cultural methods for managing nematodes on vegetables and ornamentals. Acta Hort 911:185-198

Westerdahl BB (2020) Evaluation of trap cropping for management of root-knot nematode on annual crops. Acta Hortic 1270:141-146

Westerdahl BB, Giraud DD (2017) New products for managing lesion nematode on Easter lilies. Phytopathology 107(S5):25

Westerdahl BB, Radewald JD (2011) Natural products for nematode management in tomatoes. Acta Hortic 914:275-280

Westerdahl BB, Giraud D, Etter S, Riddle LJ, Anderson CA (1998) Problems associated with crop rotation for management of Pratylenchus penetrans on Easter Lily. Suppl J Nematol 30(4S):581-589
Westerdahl BB, Hasey JK, Grant JA, Beem LW (2013) New products for management of lesion and ring nematode on walnuts. 2013 APS (The American Phytopathological Society) Annual Meeting, Austin, TX. https://www.apsnet.org/meetings/Documents/2013_ Meeting_Abstracts/aps2013abP320.htm. Accessed 16 Sep 2020

Williamson VM, Caswell-Chen EP, Westerdahl BB, Wu FF, Caryl G (1997) A PCR assay to identify and distinguish single juveniles of Meloidogyne hapla and M. chitwoodi. J Nematol 29:9-15

Publisher's Note Springer Nature remains neutral with regard to jurisdictional claims in published maps and institutional affiliations. 